\title{
The Empire and the Egyptians
}

\author{
A Multi-disciplinary \\ Approach to Global Journalism Studies
}

\author{
ELISABETH EIDE
}

\begin{abstract}
This article explores how three different analytical approaches to texts may work together to a certain extent in a critical approach to journalistic representation, in this case of the "non-western" world. Focusing on short news items dealing with the nationalist uprising in Egypt in 1919, the texts are analysed using critical discourse analysis, but also inspired by Said's Orientalism critique, Bourdieu's field theory including the notion of journalism as an autonomous field, albeit with a weak autonomy.
\end{abstract}

Key Words: Bourdieu, discourse analysis, empire, Fairclough, field theory, journalism, orientalism, othering, Said

\section{Introduction}

Yesterday's newspaper read: "Brunette stabbed to Death" and "10 000 Iranians died in an Earthquake". I wonder what color hair they had.

Abbie Hoffman

The history of journalism could well be in large part the story of an impossible autonomy - or the unending story of an autonomy that must always be rewon because it is always threatened.

\section{Patrick Champagne}

In the first half of the 20th century, people from the Nordic countries did not travel very far. Their knowledge of the non-western world came largely through radio and newspapers, and most often as very short news items. This "world in a nutshell" format illustrates how the world was often represented ${ }^{1}$.

This article will explore how some short news items from the Middle East may be well suited for analysis from various angles: Orientalism critique, because the stories often are cross-continental representations (of the Orient); field theory, because it helps us to better understand the structures influencing journalism and the struggles within the profession at a particular time; and discourse analysis, because it allows us to study the text both at the micro level and in its professional and societal context. Three texts about a national uprising in Egypt will be examined below, and in the end some parallels to the present will be suggested. 


\section{Media and the Other}

The expressions Other and othering have been "a la mode" in post-colonial theory for the past three decades, and have been integrated into international studies of both literature and media output to highlight linkages between international (colonial, neo-colonial, etc.) power relations and discourses (re)produced in texts.

In elementary psychology, the other is anyone who is separate from one's self, starting out with a child's separation from the mother. It is a normal psychological reaction, crucial for locating one's place in the world, but also for defining what is "normal", and thus for situating one's particular self inside a perceived "normalcy" - or, for that matter, outside or on the fringes of that normalcy. However, what is spontaneously experienced as "a distant Other", whether as gender, class or ethnicity, may vary substantially within a culture - and within subcultures - and these often spontaneous reactions may be subtly influenced by the relations of the powerful versus the disempowered in a given society, or on a global scale.

\section{Postcolonial Other}

The media's role in constituting a national identity - and in defining the nation (whether "blood-related" or citizen-based) via difference from Others - is of special importance. This is particularly emphasized in the history of empires. The colonized subject was treated and characterized as the Other, linked to savagery and primitivism, represented as childlike and undeveloped (Said 1978, 1994, Nandy 1990). Imperial discourse provides the terms in which the colonized subject gains a sense of his or her identity as Other (dependent and different) and offers three main alternative strategies for the colonial subjects: Passive adaptation/resignation, active mimicry (through alliance and identification with the Empire) or resistance. This process of colonial Othering provided the rulers with an ideological framework for understanding the world and for their own self-esteem. In this light, we may also see the concept development as being charged with presuppositions of hierarchies, be they of an economic, religious or cultural nature. In such a context, the modern West most often serves as a yardstick.

The question arises as to whether the frequent application of the term Other has made academics partially blind to changes in a given society (both local and global) and too eager to search for difference and hierarchy in media representations of marginalized groups and regions, instead of documenting new versions of "normalcy" and "third space occupancy". Homi Bhabha highlights a non-static in-between-ness, claiming that migrants occupy a third space of sorts, which neither corresponds to the country of origin nor to the present country of settlement (1991). A related notion is that of trans-nationality, differing from globalization in the sense that it is rooted in, but also transcends, one or several nation-states (Fuglerud 2004), a reality that in the $21^{\text {st }}$ century seems to be better understood and accepted by both journalists and audiences. We may also envisage people belonging to the majority in a country of settlement, entering and feeling (more) at home in such an open space.

\section{Micro-versions of the World}

A deeper understanding of the history of media representation of marginalized groups (and continents) is at best very incomplete in Nordic media studies - and improved analytical models and concepts would also be helpful in historical studies of journalism. 
From a historical study of Norwegian press and representation of the world at large ${ }^{2}$, I have selected three texts representing Egypt in 1919 to - at least partly - demonstrate how an analysis may benefit from various perspectives. They all belong to the genre of small news items, constituting around fifty per cent of the news coverage of the nonwestern world in our study. These texts offer micro-versions of world events, sometimes in a very "neutral" language, but still - as we shall see - containing value-laden expressions.

Gunilla Byrman defines the short news item ("notis") as a "short everyday text strongly imbued with conventions [of the time and culture]" (Byrman 1995). One does not expect this genre to contribute to analysis of a situation, but one may still trace editorial choice, interpretation and analysis between and ahead of the lines. According to Byrman, this kind of news item also contributes to confirming the existing power relations, but the (implied) reader takes part in the interpretation by supplying the short text with the missing information (from her own existing knowledge and world outlook) through inference.

The three texts all refer to the national uprising in Egypt in 1919, which had started the year before in November, when a delegation lead by Sa'd Zaghlul Pasha demanded autonomy for Egypt and wanted to travel to England to express their demands. The British refused this, and arrested Zaghlul. A widespread revolt supporting independence for Egypt followed. ${ }^{3}$

\section{A Serious Situation in Egypt}

(Text 1)

[...] London, 22. March.

To Reuter's Agency it is reported from Cairo the 15th of March: The past two days have been quiet, except for a clash with an armoured vehicle yesterday, in which 13 demonstrators were killed and 27 wounded. The streetcar traffic is partly restored. [...] In the provinces some demonstrations have taken place, and of these some were peaceful while others required military interference. (Tidens Tegn $23^{\text {rd }}$ of March 1919, my translation)

The most striking feature of this text is what is missing, i.e. the lack of Empire agency. The left-out agency in this case (was the armoured vehicle unmanned?) contributes to transferring the responsibility for the tragedy to the people (dead and wounded) who happened to "clash" with the vehicle. From the last part of the text it is understood that the agents (again, the Egyptians) are responsible for the military action (presumably) taken by the British and their allies. This unequal emphasis of agency contributes to a lopsided dichotomy between the "unruly" Egyptians and the (presupposed) agents of order and peace. Furthermore, the way in which concerns about street communication is textually combined with reference to the dead and wounded Egyptians may serve as a diminishment or trivialization of the tragedy of lives lost - a hierarchical othering (they of lesser value) of sorts. An imagined readership seems presupposed to side with the (not mentioned, tacitly understood) Empire part of the conflict.

This short preliminary and sketchy analysis demonstrating Empire-inspired othering may serve as an appetizer to a more complex approach. In the following, an attempt is made to connect several critical approaches, such as Orientalism critique, discourse analysis and field theory, in order to enrich the studies of representation of the "traditionally distant Other" - and simultaneously take seriously the particularities of the struggles within the field of journalism - as well as the texts produced by actors in the field. 


\section{Orientalism and Journalism}

Edward Said finds that the principal methodological devices for the study of authority (historical and personal) in Orientalism are strategic location and strategic formation. The first is a way of describing the position of the writer in a text "with regard to the Oriental material he writes about", and the second one is:

[...] a way of analyzing the relation between texts and the way in which groups of text, types of texts, even textual genres, acquire mass, density, and referential power among themselves and thereafter in the culture at large. I use the notion of strategy simply to identify the problem every writer on the Orient has faced: how to get hold of it, how to approach it, how not to be defeated or overwhelmed by its sublimity, its scope, its awful dimensions. Everyone who writes about the Orient must locate himself vis-à-vis the Orient; translated into his text, this location includes the kind of narrative voice he adopts, the type of structure he builds, the kinds of images, themes, motifs that circulate in his text - all of which add up to deliberate ways of addressing the reader, containing the Orient, and, finally representing it or speaking on its behalf (Said 1995: 20).

Strategic location may correspond to the relation between the reporter and the reality she observes and may imply various positions from hierarchical to more symmetrical approaches to the Other. In the above news text, the reporter is unknown and is simultaneously constituted by several persons: at first, somebody who is on the spot (Cairo) reporting to Reuter's, identifying with the colonial power; next, the reporter(s) in the editorial rooms of Reuter's and; third, the newspaper Tidens Tegn, the latter supposedly handling the Reuter messages from Cairo routinely, the event in Cairo being just one of many in a large chaotic world.

Strategic formation may be interpreted as situating a text in its societal, discursive and generic context, which will be dealt with later in this essay. Said's location and narrative voice is related to what in textual analysis is often called perspective and may link up with the gaze: through which eyes did the initial reporter observe the uprising?

In the final phrase of the above excerpt, Said refers to an important choice that is not limited to studies of the Orient: whether to represent (give voice) and/or to speak on someone's behalf. And if the Other is allowed to speak, will it be merely as a "case" (handily illustrating a point) or as a person granted a degree of authority? This question is important in an analysis of the "representing intellectuals", a privileged group to which journalists may be said to belong, even if media structures often put constraints on their practice.

\section{Representation and Mis-representation}

The critical studies of Orientalism and othering are useful to media researchers, in the sense that they have introduced alternative ways of reading texts produced in one culture but still representing cultures "outside"; i.e. cross-cultural encounters. In Orientalism, Said is preoccupied with the ways in which literature produced in a colonial situation often represents the colonial subject as being of lesser value, more primitive, emotional and less rational, less able to determine her own future - and simultaneously taking the unequal relationship (or indeed the Other rendered invisible) as the "natural order of things". 
Journalism may be studied in the light of these powerful colonial adaptations, as Said has suggested, but also in the post-colonial era. In a study of the coverage of the Iranian revolution, he registers a Western consensus behind the news, a consensus that, according to him, is the culture (Said 1981: 48-49). He expects journalists to take part in real (non-forced) encounters with the foreign cultures, and invites them to improve their professional self-reflections in the project of interpretation. In his opinion very few of them do so. Therefore, news journalism covering the Middle East is largely ethnocentric and focuses mainly on Oil and Islam (op. cit. 101, 142). Said has been criticized for determinism, in the sense that he writes of text (fiction or non-fiction) as being closely linked to the imperial powers. He admits, however, the existence of some exceptions to the 'rule', and mentions a few journalists who covered the revolution in a more comprehensive and less biased way, especially in Le Monde (Said 1981: 116-120). He, thus, demonstrates openness to alternative, non-Orientalist representations. In other words, where there is mis-representation, there may also be more correct and balanced representations, as critics like Swedish ethnologist Magnus Berg have suggested (Berg 1998). Thereby, both Said and one of his critical adherents seem to recognize the struggle (discourse and counter-discourse) within journalism (also when covering the Orient), and thus the room for individual variation, albeit demonstrating a strong link between mainstream representation of the Other and the outlook of the powerful ${ }^{4}$.

In other words, journalistic representation of the "Oriental Other" may be linked to the discourses of the powerful, but also to counter-discourses (often inspired by oppressed and marginalized groups and societies) challenging the notion of the Other as inferior, subject to neglect or denigration. We may conclude, thus, that Said in part of his work sees journalism - and the journalism profession - as being in possession of a certain degree of autonomy.

There is a need to study journalism both from the outside moving inwards and from the actual text moving outwards ${ }^{5}$. Traditionally, most studies from the "outside" have been rooted in the social sciences.

\section{Bourdieu's Field Theory and Journalism}

To think field theory is to think in terms of relations. Pierre Bourdieu's field theory portrays modernity as a process of differentiation into semiautonomous and increasingly specialized spheres - or fields - of action. Individuals do not simply act to maximize their rational self-interest, but are woven into social relations in processes not always marked by this self-interest (Benson\&Neveu 2005:3).

But how does journalism qualify? Bourdieu recognizes journalism as a field of its own, an autonomous field, but with a weak autonomy, a microcosmos in macrocosmos. By stating this, he challenges the notion that the media are simply part of a structurally determined ad-saturated, rating-driven culture. Simultaneously, he considers the journalistic field to be closely linked to the field of power, as it tends to engage agents who dispose large amounts of capital, that is, economic, political and cultural capital.

The field of journalism lives partly according its own "laws": institutional logics ("this is news", "this is not a story"), editorial room hierarchies, competition or cooperation among journalists and genre conventions. Being a field means sharing doxa; i.e. tacit presuppositions constituting a universe of thought accepted to a certain degree by all actors. New forces in the field opt either for transformation or preservation (chal- 
lenge or adaptation), depending on institutional culture, individual capital and courage, etc.

In the field of journalism, economic capital may be said to represent circulation, advertising interests and rating, while cultural capital is connected to intelligent communication (columns, editorials), in-depth reporting and award-winning journalism - all markers of professional prestige.

Bourdieu and his adherents recognize the struggles within the field, and the individual deviances from what is (institutionally) expected. Counter-discursive critics underline this and have tried to represent other experiences, i.e., those of various marginalized groups. Critique from such groups will also challenge the relations of power, often central to journalistic attention.

Bourdieu distances himself from Neil Postman (who sees the media (TV) as the main obstacle to public enlightenment and participation), Habermas (who sees the public sphere as fundamentally commercialized) and Chomsky (who emphasizes the crucial role of media ownership) (Benson \& Neveu 2005: 8-9). Thus, he underlines the relative autonomy of the journalistic field. But as Patrick Champagne also states, this autonomy is fragile, and those who struggle to retain it seem to be in a defensive position.

Erik Neveu, one of the editors of a recent volume discussing Bourdieu's field theory and its impact for journalism studies (Neveu 2005: $208 \mathrm{ff}$ ), suggests a three-step field analysis in journalism. The first step is an analysis of a room of production, a structural system of institutions (ownership, etc.), organizations and social roles. This also entails recognizing this as a room of struggle, one of the struggles being to define good journalism $^{6}$. This is where different kinds of prestige come into play: prestige linked to the (traditionally relatively high) cultural capital of prestigious journalism or to the market parameters (which stories "sell"). Important is also the field's relation to other fields: for example business papers' strong links to business life, newspapers tied to certain cultural or religious traditions, others relying on readership in agricultural and fisheries communities in some regions, etc.

The second step is entering the production within the field. This is where professional experience comes into play, such as the ongoing development of professional codes, the tacit presuppositions found in newsrooms, ethics and generic capacity. Journalism constitutes discursive production, but actors in the field also represent an interpretative society ${ }^{7}$. Interpretation, such as that taking place in literature and science, is almost always done on behalf of - or with reference to - somebody, but is simultaneously a product of one's own societal role and imagination.

Neveu's third step is reception, audience studies. In this endeavour, one needs to analyse the various productions of meaning in different subcultures of audiences, searching both for likeness and difference ${ }^{8}$.

Altogether this is a rather comprehensive model for analysing media production and consumption. But others may still enrich it.

\section{Critical Discourse Analysis and Journalism}

In journalism, as in the study of other fields of discursive practice, discourse analysis means a set of approaches that have to be tailored to a certain extent to a specific mass of texts. For the analysis of journalistic texts, generic competence and knowledge of the development of the profession are relevant. In trans-continental media analysis, for ex- 
ample studies of Nordic media representation of the so-called non-west, the analysis may work at several levels and also negotiate between the levels in a multi-disciplinary approach.

Norman Fairclough offers the following definition of discourse: "an element of social practices which constitutes other elements as well as being shaped by them" (Fairclough 1999: ix). The combination 'being shaped by' and 'constitute' offers a useful, dialectical approach, constitute seen as being largely synonymous with represent. The latter may be exemplified by dominant groups in society constituting their 'truths' by imposing specific knowledge, disciplines and values upon dominated groups, as in war propaganda ('good versus evil'). What preserves power is the way in which discourse penetrates and produces things, luring us into pleasure and various forms of knowledge (Winther Jørgensen \& Philips 1999: 22). In history, colonial discourse may be seen as a complex of signs and practices that organize social existence and social reproduction within colonial relationships - thereby causing people to accept these relationships more easily.

\section{Creating Links}

Fairclough further sees discourse analysis as "an attempt to show systematic links between texts, discourse practices and sociocultural practices" (Fairclough 1995: 16-17).

Discourse practice mediates between the textual and the sociocultural practice, as an indirect link between text and sociocultural practice (Fairclough 1995: 59-60). Fairclough sees discourse as a way of facilitating analysis of a text's relation to society: both as a way of 'explaining' aspects of the text and as a way of studying the impact of texts on the reader(s).

Three levels: Fairclough emphasizes his concern at three levels: Media texts as texts (linguistic practice), as discourse practices: "the ways in which texts are produced by media workers in media institutions and the ways in which texts are received by audiences" and sociocultural practices: "constituting parts of the context of discourse practice" (Fairclough 1995: 16). As we may observe, these steps correspond to a certain degree to Neveu's steps, which are inspired by Bourdieu's field theory.

Thus, Fairclough offers a model for studying the communicative event, moving from the text outward, while scholars in the Bourdieu tradition seem to start from the "outside" and move inward. Said's approach has mainly been literary studies with colonial history as a backcloth. A central perspective of his is "contrapuntal reading ${ }^{10}$ ", that is, reading a text from the perspective of the colonized subject, related to "the subaltern view" (Spivak 1988), and comparing this reading to the more conventional (power-related) approaches.

Fairclough's model is figuratively not unlike a set of Chinese boxes. Fairclough suggests that an analysis of media texts (and other texts) can highlight three groups of questions concerning media output: The representational level: How is the world that is, events, relations etc., represented? The identity level: What identities are established for those involved in the programme or story, i.e. the reporter, the audience, the politician and the audience, the sources and the audience? And last, but not least, the relational level: What relations are established between the involved parts: reporter/ source, reporter/public, expert/public, politician/public, and source/public? By suggesting such specific questions he contributes to the richness of the approach. 


\section{Restoring Order in Cairo and Alexandria}

To investigate the feasibility of the multi-disciplinary approach, I have selected two ${ }^{11}$ additional texts, covering the same events in Egypt, but not from the same newspaper as Text 1.

\section{Quiet in Cairo and Alexandria}

(Text 2)

London, $22^{\text {nd }}$ of March

Reuter's Agency telegraphs, that is, telegrams from Egypt, dated $21^{\text {st }}$ of March, show that the situation is definitely better. Order has been restored in several cities, and in Cairo and Alexandria it is absolutely quiet. The telegraph connection with Tantah has been restored. It is reported that the better classes of the natives in certain provinces are doing their best to restore order. The only factor which can create unrest is, as is reported, that the Bedouins are gathering in significant numbers, but their only aim is plundering. (Aftenposten 23.03.1919, Dagbladet 22.03.1919)

\section{Colonial and Class Affiliation}

Just as in Text 1, this text has left out - apart from the headline - one main agent (invisible agency): the British Empire, with its representatives and allies: "Order has been restored..." A tacit presupposition is that when the British gain the upper hand, it is "definitely better" for Egypt. The resistance, here represented as "the Bedouins", are referred to in a somewhat reductionist manner, as "plunderers", i.e. criminals, not as a political opposition. On the other hand, the "better [here supposedly applied synonymously with upper] classes" are represented as being on "our" side, helping to restore order.

Seen from an Orientalism critic's point of view, this is a classical piece of representation via binary opposites: The orderly $U s$ (Empire-oriented) versus the disorderly and irrational Them, Oriental Others (the Bedouin criminals). The implied reader seems here expected to side with the British Empire ${ }^{12}$. The "neutral" source of information, represented by the "it is reported", may also contribute to the authority of the text. Thus, it can be read as an example of agency-transmitted on-the-surface "neutral" information, but laden with the ideology of the main Empire of the time.

The above text was printed in the (then) conservative newspaper Aftenposten. The text in liberal Dagbladet ${ }^{13}$ is almost identical, but has another headline: The English seem to be gradually becoming the rulers of Egypt, in other words a more explicit way of presenting the events - and also a headline containing more explicit Imperial agency. In addition, their reference is that "Reuter's agency "experiences" that telegrams from Egypt ..."

The almost identical versions may indicate that when it comes to foreign coverage of "remote" events early in the $20^{\text {th }}$ century, editorial political differences come into play to a lesser degree - overshadowed by a shared acceptance of the colonial order - or more pragmatically that the usual dependence on international agencies for foreign news often minimized differences.

In 1919, Norway had been an independent nation for fourteen years. From this historical perspective, one might suggest that this newly won independence would cause sympathy for colonized nations struggling for national independence, but such sympathy is rarely demonstrated in the press ${ }^{14}$. 
Furthermore, at that time, the journalism profession was less developed and journalists far less educated than today. A "natural" suggestion in the aftermath of World War I may be that the press would be more closely linked to the interests of the nation and its foreign policy. These links were probably strengthened by a common-sensical political acceptance of colonialism and the larger European nations' scramble for world hegemony.

To answer Fairclough's three questions: In this text, a world is represented in which Empire is the natural order of things, albeit threatened by criminals. Second, the identities traced are four: (1) The invisible, neutral voice (the agency and its sources); (2) the "good ones" (our guys), i.e. the "better classes" with which the reader is supposed to identify; and (3) the "bad ones", i.e. the Bedouins, whose only aim is to harm society; and last (4) the readership, presupposed to be sympathetically inclined towards the British. Third, the relations observed are largely invisible in such a short news text, but one senses the initial reporter's sympathies for the "better classes", and the opposite feeling for the rebel-like (bandit) Bedouins.

Genre-wise, the way in which the agency (Reuter's) news is presented looks rather clumsy with today's eyes, as contemporary newspapers present their agency sources in a more brief and discrete way. A question to be further investigated is why reporters construct the short news in this particular style, historical facts and political allegiances being only part of the answer. Fairclough is often concerned with how discourse from one field permeates language and representation in another field, as when commercial language is applied in academic institutions to better "sell" their services. A degree of interdiscursivity may be observed in the text, as "order" and "plundering" are concepts often applied in the discourse of crime. The concepts applied when representing a national uprising serve the purpose of criminalizing the opponents of the "natural order".

\section{Exposing Double Standards}

Another text seems to be more preoccupied with Imperial agency and its interpretation of nationalism.

\section{In Egypt}

(Text 3)

the situation has deteriorated. The British dismissal of the nationalist leaders has of course enraged the people. The idea of nationalism, as we know, is not as fully accepted in practice within the British Empire as it is in theory among the British leaders. (Stavanger Aftenblad 22.03. 1919)

The liberal paper Stavanger Aftenblad is published in south-western Norway, an area with a strong and often radical lay Christian tradition. This is one of the explanations why the paper has a larger coverage of missionary activities than do most others ${ }^{15}$ (and gives higher priority to coverage of the non-west (Eide 2002)), thereby also opening up to a universe of sources "out there", sought out and quoted in the foreign news articles from non-western countries. This may also at times have led to a more developed empathy for the ordinary people inhabiting the colonies.

The above is a short text dated one day ahead of Text 2, but states that the situation in Egypt is "deteriorating" - contrary to the conclusion of the two newspapers from the capital. This text does not refer to any telegrams from agencies, and genre-wise may be labelled as something in-between short news and comment, but its spatial context 
within the paper is a row of small international news stories (similar to the contexts of Texts 1 and 2). Today, it might generically have served as a "sub-editorial", a smaller text printed below the main editorial of a newspaper.

In writing that the British act of dismissal has "of course" enraged "the people", the author of the text implies that revolt is a justified action, more justified than the acts of the Empire to provide law and order.

In this text, this "natural world order" is challenged, as the text exposes the double standard of the British Empire by highlighting their non-acceptance of Egypt's nationalists and their demands. We find a different kind of binary opposite - often applied in political journalism - the position of theory (the lofty ideals) versus practice (the grim realities). Could this be an example of the field of journalism being inspired by the religious field (or the subfield of lay Christians), and could the statement of double standards be interpreted as a practice-as-you-preach Christian morality inspired by the politically radical lay Christian tradition in this newspaper's main area? Or is the breach of genre (a non-agency short news item bordering on comment) of more decisive importance, allowing for more individual journalistic judgement?

The identities set up in the text are five: (1-2) Two of them may be partially merged, as the usage of the word we in "as we know", may be addressed to an enlightened reader who is as fully aware of the negative aspects of colonialism as the writer is, although it may also be read as the editorial "we". Furthermore, (3) the nationalist leaders are posited partly as victims (as they are dismissed), and (4) the people sympathizing are represented as reacting with a justified rage (no mentioning of Bedouins here). The British leaders (5), on the other hand, are represented as untrustworthy and discriminatory bearers of double standards.

Thus, one may conclude that this text opposes the mainstream Orientalist representation of the Middle Eastern Other (of that historical period) and represents a rare ${ }^{16}$ counter-discursive example, opposed to the widespread acceptance of the colonial order, thereby deviating from the hegemonic discourses of the historical period.

\section{Struggle and Individual Deviance}

The two texts cited above also demonstrate Bourdieu's reference to the struggle within the field of journalism, or as it were, both the autonomy of the field and the individual deviance permitted, in this case by a liberal regional newspaper (and its individual reporter/editor), from the mainstream political support to one of Norway's closest allies and trading partners, and to the ideology of colonialism as a taken-for-granted civilizational endeavour. One may also suggest that while a traditional Orientalist (Empire-inspired) approach to the crisis in Egypt seems to be the rule, a certain space was left for counter-discursive newspaper texts, but a stronger conclusion of course requires a broader investigation ${ }^{17}$.

In the recently published volume on Bourdieu's journalism critique, there is not a single reference to Fairclough and critical discourse analysis - or to Said's Orientalism critique. This is an attempt to show how the three approaches may enrich analysis of journalism if applied together, also recognizing their correspondence to each other.

What do these three approaches share? (See also Appendix 1)

First and foremost they all adhere to an anti-hegemonic media critique, but also distance themselves from a determinist mode of analysis, thereby admitting to a certain degree of journalistic autonomy. They see the journalistic field as an important, power- 
ful one, but simultaneously weak, in the sense that journalism is being greatly influenced by other powerful fields. They recognize both the need to reject media centrism (an analysis that does not take exterior, societal influence into account) and the importance of a specific analysis of the production going on in the field, taking the particularities of the journalistic field (and profession) into consideration.

For example, can one not see a connection of sorts between Fairclough's interdiscursivity and Bourdieu's heteronomy (i.e., a field being influenced by or to a degree intertwined with other fields, i.e. a field with a weak autonomy), as when the anti-colonial Egyptians are represented using terms normally applied to criminals? Fairclough himself suggests that identification ${ }^{18}$ in discourse analysis brings Bourdieu's habitus ${ }^{19}$ into consideration (Fairclough 2004: 29). Can one not also see the correspondence between Spivak's Othering and Fairclough's action (as the professional's relation to sources, objects and audience), in the above case exemplified by the (invisible) writer who is treating the colonial subjects as irresponsible, unruly and in need of military intervention? Or between this Othering imbued with the marks of Empire and Said's analysis of the way in which colonial power is reflected in texts produced under colonialism - and Bourdieu's analysis of the journalistic field as strongly influenced by the field of power - such as when the mainstream messages about the Egyptian uprising do not challenge the British Empire?

I think there is a need for further investigation of the common ground between these three directions - all of which refer somehow to the relationship between knowledge and power. In a period of increased emphasis on globalization (albeit not a new phenomenon), this kind of analysis may be more in demand and could represent a challenge for media scholars engaged in inter-continental studies of journalism.

Students and researchers in the journalistic field have to face a world in which part of the journalistic practice as well as media use is becoming more trans-national and may feel the need for a more multi-disciplinary approach to the field. In today's world "the Empire talks back", as seen, for example, by TV channels such as Al Jazeera going global and other regional plans for worldwide distribution of both news (for example Telesur, based in Venezuela) and serials. Myths and stereotypes will increasingly be scrutinized whether they occur in the traditional "West" or elsewhere.

The struggle for representation in today's globalized world is more important than ever, and an essentialist or marginalizing representation of the non-western Other may contribute to bipolar thinking that triggers conflict and ignores the universal experiences shared by all humankind as well as the universal value of a human life.

\section{Notes}

1. In a larger ongoing research project Norway from half-colony to humanitarian superpower $-a$ hundred years with the Other in the Norwegian Press (Simonsen and Eide 2003-), we have observed that the genre most frequently represented is precisely this short news story, usually a limited one-column article, sometimes a picture with a very short text.

2. E. Eide and A.H. Simonsen: Norway from half-colony to humanitarian superpower: a hundred years with the Others in the Norwegian Press (2003-). Non-western is a problematic concept as both the "non-west" and the "west" are everywhere in today's world (historically less so). In the non-west, we have included Asia, Africa, the Middle East, Oceania (minus Australia and New Zealand) and Latin America.

3. Our material consists of two synthetic weeks per year $(1902,1919,1928,1935,1947,1953$, 1967, 1976, 1982, 1991, 2002) from seven daily newspapers, starting each year in February. Therefore, much of the coverage of this uprising is (so far) not included in our material. 
4. What does "power" and "the powerful" imply? In this context it is a concept mainly associated with people who possess large amounts of economic or political - and to a certain extent - also cultural capital.

5. For a more thorough elaboration of this perspective, see Eide 2002.

6. "Is this award-winning journalism or journalism that helps sell more subscriptions or copies?" is one of the questions posed.

7. Corresponding to Said's communities of interpretation: Everyone shapes his Others and different 'communities of interpretation' continuously interpret and reinterpret. The interpretation may be linked to political and economic power (or lack of such power), but also to fear of external enemies, as Said suggests in his studies of Orientalism and the coverage of Islam (Said 1981, 1995).

8. I shall not dwell on this step here, as my main point is to link the three approaches in general, and because my field of study is historical texts from 1902 to 2002 - which makes audience studies rather difficult.

9. The various ways this comes forward are: situational: "the specific social goings-on which the discourse is part of"; institutional: "the institutional framework(s) that the discourse occurs within and societal: "the wider social matrix of the discourse

10. Contrapuntal reading: "simultaneous awareness both of the metropolitan history that is narrated and of those other histories against which (and together with which) the dominant discourse acts" (Said 1994: 59-60).

11. Really three, as two variations of the same are printed in two different newspapers.

12. Not a rare presupposition. Norway, albeit officially "neutral" in World War I, was in practice recognised as England's "neutral ally" (Riste 1965).

13. Both newspapers are published from the capital, Oslo.

14. The two Social Democratic newspapers in our sample sometimes deviate from this acceptance, the year 1919 being one of the most radical years of Norwegian Social Democracy - and the newspapers' party affiliation being considerably stronger than today.

15. About half of all texts treating missionary activities (from 7 newspapers in the ongoing research project) originate from this newspaper.

16. In this historical period, in our material (Simonsen \& Eide, op.cit) this text represents an exception.

17. The majority of the Egypt texts from 1919 support this suggestion.

18. Identification: unlike action, which is to do with relations to others, "is to do with relations with oneself, ethics and the "moral subject" (Fairclough 2004: 28)

19. Habitus: A person's embodied dispositions to see and act in certain ways based upon socialization and experience, according to Fairclough partly their dispositions to talk and write in certain ways (Fairclough 2004:29)

\section{Literature}

Ashcroft, Bill; Griffiths, Gareth; Tiffin, Helen (1989): The Empire Writes Back. London: Routledge. Ashcroft, Griffiths \& Tiffin (1998) Key Concepts in Post-Colonial Studies. London: Routledge.

Benson, Rodney \& Neveu, Erik (eds.) 2005) Bourdieu and the Journalistic Field. Cambridge: Polity Press.

Berg, Magnus (1998) Hudud. En essä om populärorientalismens bruksvärde och världsbild. Stockholm: Carlssons.

Bhabha, Homi K. (1990) Nation and Narration. London/NYC: Routledge.

Bhatia, Vijay (2001) Generic Integrity in Professional Discourse; lecture at Genre 2001. Oslo: Høgskolen i Oslo.

Bourdieu, Pierre (1998) Om fjernsynet. Oslo: Gyldendal.

Bourdieu, Pierre \& Wacquant, Loïc J.D.(1993) Den kritiske ettertanke. Oslo: Samlaget.

Champagne, Patrick (2005) The "Double Dependency": The Journalistic Field Between Politics and Markets, in Benson \& Neveu, op. cit.

Chomsky, Noam (1988) Manufacturing Consent. The Political Economy of the Mass Media. New York: Pantheon Books.

Chouliaraki, Lilie \& Fairclough, Norman (1999) Discourse in Late Modernity. Edinburgh: Edinburgh University Press.

Eide, Elisabeth (2002) "Down there" and "Up here" - "Europe's Others" in Norwegian Feature Stories. Oslo: University of Oslo. 
Eide, Elisabeth \& Simonsen, Anne Hege (2004) Å se verden fra et annet sted. Medier, norskhet og fremmedhet. Oslo: Cappelen.

Eriksson, Catharina, Eriksson Baaz, Maria \& Thörn, Håkan (ed.) (1999) Globaliseringens kulturer. Den postkoloniala paradoxen, rasismen och det mångkulturella samhället. Lund: Nya Doxa

Fairclough, Norman (1992) Discourse and Social Change. Cambridge: Polity Press.

Fairclough, Norman (1995) Media Discourse. London: Arnold.

Fairclough, Norman (2004) Analysing Discourse. Textual Analysis for Social Research. London: Routledge.

Fürsich, Elfriede (2002) How Can Global Journalists Represent the 'Other'?, Journalism 3(2002) 1. London: Sage.

Hall, Stuart (1992) The West and the Rest: Discourse and Power, in Hall/Gieben: Formations of Modernity. Cambridge: Polity Press.

Hall, Held \& McGrew (eds. 1994) Modernity and its Futures. Cambridge: Polity Press

Holmberg, Claes-Göran \& Svensson, Jan (1995) Medietexter och medietolkningar. Nora: Nya Doxa

Jørgensen, Marianne W. \& Phillips, Louise (1999) Diskursanalyse som teori og metode. Roskilde: Roskilde Universitetsforlag.

Maalouf, Amin (2000) On Identity. London: The Harvill Press.

Malik, Kenan (1996) The Meaning of Race. Race, History and Culture in Western Society. London: Macmillan.

Nandy, Ashis (1990) The Intimate Enemy. Loss and Recovery of Self Under Colonialism. Delhi: Oxford University Press.

Nandy, Ashis (1998) Exiled at Home. Delhi: Oxford University Press.

Nandy, Ashis (ed. 1988) Science, Hegemony and Violence. Delhi: Oxford University Press.

Riste, Olav (1965) The Neutral Ally: Norway's Relations with Belligerent Powers in the First World War. Oslo: Universitetsforlaget.

Said, Edward W. (1995) [1978]: Orientalism. London: Penguin

Said, Edward W. (1981) Covering Islam. London: Routledge \& Kegan Paul

Said, Edward W. (1985) Orientalism Reconsidered, Cultural Critique, 1, Fall 1985. Cary, N.C.: Oxford University Press

Said, Edward W. (1994) Culture and Imperialism. London: Vintage

Sardar, Ziauddin (1998) Postmodernism and the Other. London: Pluto Press

Spivak, Gayatri (1988) Can the Subaltern Speak? i Grossberg L. \& Nelson, Cary (eds.) Marxism and the Interpretation of Culture. Houndmills: Macmillan. 


\section{Appendix 1.}

Three Approaches, Inspiring Analysis of Journalistic Texts

\begin{tabular}{|c|c|c|}
\hline $\begin{array}{l}\text { Orientalism critique, post- } \\
\text { colonial theories, othering } \\
\text { (Said, Spivak, etc.) }\end{array}$ & $\begin{array}{l}\text { Field theory (Bourdieu, } \\
\text { Neveu and Benson, etc.) }\end{array}$ & $\begin{array}{l}\text { Critical discourse analysis } \\
\text { (Fairclough, Bhatia) }\end{array}$ \\
\hline $\begin{array}{l}\text { Othering as journalist's } \\
\text { relation to source or object. } \\
\text { Linked to Empire: imperial/ } \\
\text { colonial power, thus } \\
\text { incorporating } \\
\text { history.Inspired by literature } \\
\text { studies. Representation } \\
\text { (hierarchical, symmetrical, } \\
\text { reflective, "third space" } \\
\text { (difference blurred) or non- } \\
\text { representation, Eide 2002). } \\
\text { Reflecting power relations } \\
\text { (mainstream). }\end{array}$ & $\begin{array}{l}\text { Heteronomy (weak } \\
\text { autonomy), struggle within } \\
\text { the field. Incorporates } \\
\text { history in the heart of media } \\
\text { analysis. Journalism linked } \\
\text { to the field of power (e.g. } \\
\text { capital). A school of } \\
\text { sociology. History: Semi- } \\
\text { autonomous institutional } \\
\text { logic. Tool for relational and } \\
\text { spatial analysis. Journalism } \\
\text { as micro cosmos in macro } \\
\text { cosmos. Moving from field } \\
\text { inwards. }\end{array}$ & $\begin{array}{l}\text { Fairclough: Discourse as } \\
\text { text, as discursive practice } \\
\text { and social practice (seen as } \\
\text { text in context). Roots in } \\
\text { linguistic studies and social } \\
\text { science.Interdiscursivity as } \\
\text { sign of field influence (e.g., } \\
\text { from political or economical } \\
\text { to journalistic field). Moving } \\
\text { from text (linguistic practice) } \\
\text { outwards. }\end{array}$ \\
\hline Location & Habitus & Identification \\
\hline
\end{tabular}




\section{Appendix 2.}

A House with Four Rooms (a place to explore journalistic texts)

Vijay Bhatia (building on Fairclough) offers an analytical model for textual analysis that may be visualized as "four rooms" - with open doors between them. The first room is the textual one, inviting the guest to engage with the text at the micro-level. The next one is devoted to genre, and there generic knowledge (for example of the convention of short news stories) comes into play. Third: the professional room, in which one investigates the text, considering how professional and institutional values (like reflexivity, news priorities, relation to sources) come into play. And fourth: the societal room, in which the text is seen as a particular kind of societal practice, and where the historical context of a text is of great importance. In the model below, I have added a fifth room, that of the audience, as the audience is always at stake in the editorial room, either in the shape of a person who should be able to understand the message, in the shape of someone who is supposed to share the values of the media institution, in the shape of a new "target group" triggered by media competition or a combination of all three.

\begin{tabular}{|c|c|c|c|c|c|}
\hline Room & $\begin{array}{l}\text { Textual } \\
\text { room }\end{array}$ & $\begin{array}{l}\text { Generic } \\
\text { room }\end{array}$ & $\begin{array}{c}\text { Professional } \\
\text { room }\end{array}$ & $\begin{array}{l}\text { Audience } \\
\text { room }\end{array}$ & $\begin{array}{c}\text { Societal } \\
\text { room }\end{array}$ \\
\hline $\begin{array}{l}\text { Content and } \\
\text { questions }\end{array}$ & $\begin{array}{l}\text { Linguistic } \\
\text { level, meta- } \\
\text { phors. } \\
\text { Style, figures } \\
\text { of speech, } \\
\text { attributions, } \\
\text { chains of } \\
\text { referents, } \\
\text { agency, } \\
\text { voice. } \\
\text { Intertextuality, } \\
\text { interdiscursivity }\end{array}$ & $\begin{array}{l}\text { Generic } \\
\text { particulari- } \\
\text { ties. } \\
\text { The text } \\
\text { seen in light } \\
\text { of conven- } \\
\text { tions of the } \\
\text { genre, } \\
\text { eventual } \\
\text { hybrids. } \\
\text { Composition, } \\
\text { dramaturgy. }\end{array}$ & $\begin{array}{l}\text { Media } \\
\text { institution, } \\
\text { the struggle } \\
\text { within the } \\
\text { field. } \\
\text { Who is } \\
\text { allowed to } \\
\text { speak? Who } \\
\text { is assigned } \\
\text { which roles? } \\
\text { How does } \\
\text { the reporter } \\
\text { relate to the } \\
\text { sources? }\end{array}$ & $\begin{array}{l}\text { The implied } \\
\text { reader. The } \\
\text { tacitly } \\
\text { presupposed } \\
\text { "we". How } \\
\text { are the } \\
\text { readers } \\
\text { addressed? }\end{array}$ & $\begin{array}{l}\text { Text in } \\
\text { historical } \\
\text { context. The } \\
\text { media's } \\
\text { relation to } \\
\text { the powerful } \\
\text { and disem- } \\
\text { powered of } \\
\text { the time. } \\
\text { Which facts } \\
\text { are repre- } \\
\text { sented? }\end{array}$ \\
\hline
\end{tabular}


